\title{
Ion nitriding of equiatomic TiNi shape memory alloys II. Corrosion properties and wear characteristics
}

\author{
S.K. Wu *, C.L. Chu, H.C. Lin ${ }^{1}$ \\ Institute of Materials Science and Engineering, National Taiwan University, Taipei 106. Taiwan
}

Received 2 January 1997; accepted 10 March 1997

\begin{abstract}
The corrosion properties and wear characteristics of $\mathrm{Ti}_{50} \mathrm{Ni}_{50}$ and $\mathrm{Ti}_{50} \mathrm{Ni}_{40} \mathrm{Cu}_{10}$ shape memory alloys with and without ion nitriding were investigated by acid immersion test, electrochemical potentiodynamic measurement and sliding wear test. Experimental results indicate that the non-ion-nitrided TiNi specimens are easily attacked by the $\mathrm{HCl}$ and $\mathrm{H}_{2} \mathrm{SO}_{4}$ solutions. However, their corrosion properties in these solutions can be markedly improved by ion nitriding. The improved corrosion resistance is attributed to the TiN compound formed in the outermost part of ion-nitrided layers. In addition, the ion-nitrided $\mathrm{TiNi}$ specimens, being hardened by the $\mathrm{TiN} / \mathrm{Ti}_{2} \mathrm{Ni}$ compound layers, can exhibit excellent wear resistance and a low friction coefficient. 1997 Published by Elsevier Science S.A.
\end{abstract}

Keywords: Ion nitriding; Shape memory alloys; TiNi alloys

\section{Introduction}

Among the many shape memory alloys (SMAs), TiNi alloys are the most popular because they possess superior properties in shape memory effect (SME) [1] and pseudoelasticity (PE) $[2,3]$. Most of their industrial applications may not involve any corrosion problems. Nevertheless, for applications in orthopedic surgery and medical implantation, or for structural components in corrosive environments, corrosion could be a very critical problem. Several investigations [4-8] have been performed on the corrosion resistance of TiNi alloys. These studies concluded that the TiNi alloys can exhibit fairly good corrosion resistance due to the formation of a thin passive film. However, this passive film can be locally destroyed in some specific environments leading to the occurrence of corrosion. Hence, the improvement of the corrosion resistance of TiNi alloys is necessary to extend their applications in corrosive environments.

Nitriding techniques are often used to increase the surface hardness and to improve the fatigue and wear resistance of metals and alloys [9]. In Part I of this study [10], we found that the surface hardness of

* Corresponding author.

${ }^{1}$ Present address: Department of Materials Science, Feng Chia University, Taichung 400, Taiwan.
$\mathrm{Ti}_{50} \mathrm{Ni}_{50}$ and $\mathrm{Ti}_{50} \mathrm{Ni}_{40} \mathrm{Cu}_{10}$ alioys can be significantly improved by ion nitriding. This improvement in surface hardness is attributed to the formation of TiN and $\mathrm{Ti}_{2} \mathrm{Ni}$ in the surface layers. Nitriding techniques have also been used to improve the corrosion resistance of titanium and titanium alloys [11-17]. However, to the best of our knowledge, there have been few investigations on the corrosion characteristics of ion-nitrided TiNi alloys. In the present study, the corrosion properties of ion-nitrided $\mathrm{Ti}_{50} \mathrm{Ni}_{50}$ and $\mathrm{Ti}_{50} \mathrm{Ni}_{40} \mathrm{Cu}_{10}$ alloys in hydrochloric acid and sulfuric acid aqueous solutions are investigated. The effects of ion-nitriding parameters on their corrosion resistance are discussed. Meanwhile, the preliminary results of wear characteristics of ionnitrided $\mathrm{Ti}_{50} \mathrm{Ni}_{50}$ and $\mathrm{Ti}_{50} \mathrm{Ni}_{40} \mathrm{Cu}_{10}$ alloys are also reported.

\section{Experimental procedures}

\subsection{Specimen preparation}

A conventional tungsten are melting technique was employed to prepare the $\mathrm{Ti}_{50} \mathrm{Ni}_{50}$ and $\mathrm{Ti}_{50} \mathrm{Ni}_{40} \mathrm{Cu}_{10}$ (in at.\%) alloys. Titanium (purity 99.7\%), nickel (purity 99.9\%) and copper (purity 99.9\%), totaling $200 \mathrm{~g}$, were 
melted and remelted at least six times in an argon atmosphere.

Ion nitriding was carried out in an NDK furnace model JIN-6SS-C-SV. The specimen's support and holder were made of titanium to reduce contamination of the specimen surface during the sputtering process. After nitriding, the specimens were cooled in vacuum. The cooling rate was approximately $20^{\circ} \mathrm{C} \mathrm{s}^{-1}$ at the initial stage, but this rate was slow towards the end of the cooling period. The details of the specimen preparation and the ion-nitriding processes have been described in Part I of this study [10].

\subsection{Immersion test}

All immersion experiments were conducted at $25^{\circ} \mathrm{C}$ in $1 \mathrm{M} \mathrm{HCl}$ or $1 \mathrm{M} \mathrm{H}_{2} \mathrm{SO}_{4}$ solutions for 5-14 days. Following this, specimens were removed and cleaned in ethyl alcohol using ultrasonic equipment. Thereafter, they were weighed and recorded and the corrosion rates were calculated.

\subsection{Electrochemical potentiodynamic measurement}

Specimens with and without ion nitriding were examined by electrochemical potentiodynamic measurements. The experimental set-up, shown in Fig. 1, included a three-electrode system, a Nichia model NP G1001ED potentio-galvanostat, a potential scanner ES-511A and a personal computer. Scans were initiated by lowering the corrosion potential of the specimen to a pre-set value of $-1.0 \mathrm{~V}$ (versus the saturated $\mathrm{Ag} / \mathrm{AgCl}$ electrode), and then scanned to $+1.0 \mathrm{~V}$ (versus the saturated $\mathrm{Ag} / \mathrm{AgCl}$ electrode) at a rate of $1 \mathrm{mV} \mathrm{s}^{-1}$;

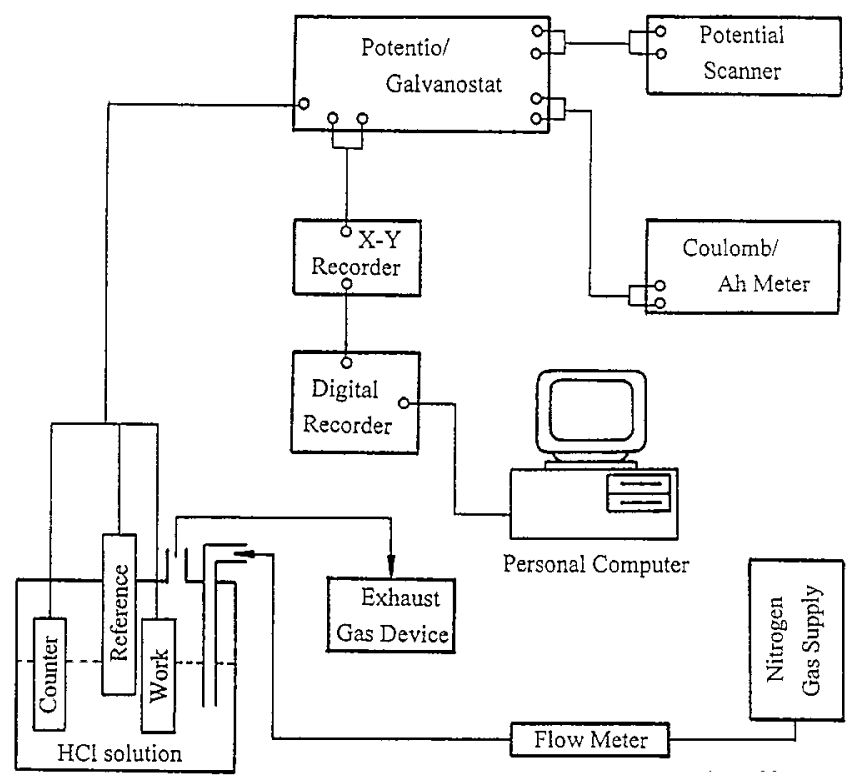

Fig. 1. Schematic diagram of electrochemical potentiodynamic instruments. following this, a scan was run from $+1.0 \mathrm{~V}$ to $-1.0 \mathrm{~V}$ at the same rate to complete a cycle. The experiment was conducted in a $0.5 \mathrm{M} \mathrm{HCl}$ solution at room temperature under static and atmospheric conditions. A platinum sheet was used as a counter electrode and oxygen was removed from the electrolyte by purging with purified nitrogen. In order to minimize the internal resistance drop in the solution, the reference electrode was positioned as closely as possible to the working electrode.

\subsection{Surface analysis and cross-section microanalysis}

After the experiment in Section 2.2, the surface of the specimens were investigated using a Philips 515 scanning electron microscope (SEM) with an energy-dispersive $\mathrm{X}$-ray (EDX) analysis facility. The cross-sections of these specimens were examined by a JEOL JXA-8600SX electron probe microanalyzer (EPMA). X-ray diffraction (XRD) tests were carried out using a Philips $\mathrm{PW} 1710 \mathrm{X}$-ray diffractor which provided $\mathrm{Cu} \mathrm{K} \alpha$ radiation. The power was $40 \mathrm{kV} \times 30 \mathrm{~mA}$ and the $2 \theta$ scanning rate was $3^{\circ} \mathrm{min}^{-1}$.

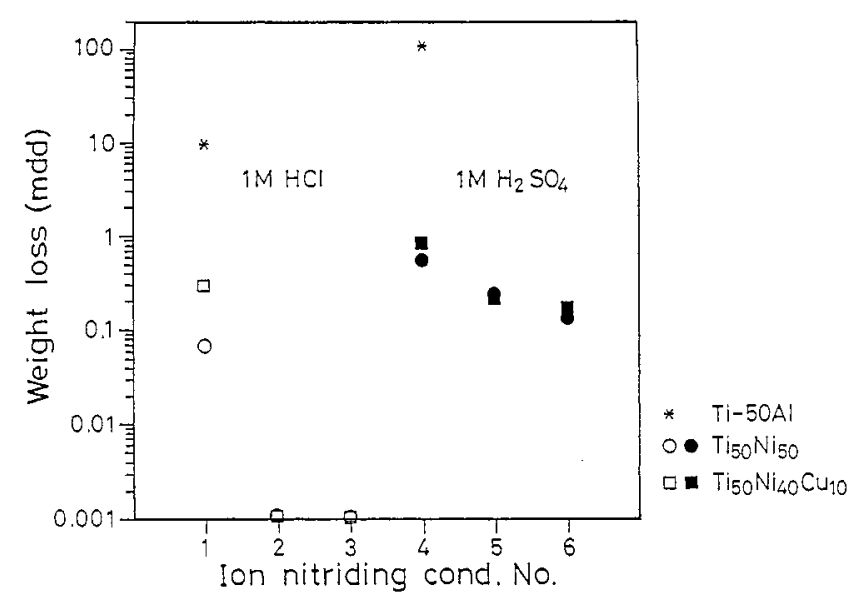

Fig. 2. Immersion test results in $1 \mathrm{M} \mathrm{HCl}$ or $\mathrm{H}_{2} \mathrm{SO}_{4}$ solutions. The ion-nitriding conditions are listed in Table 1.

Table 1

Ion-nitriding conditions of Figs. 2 and 7 (b)

\begin{tabular}{lll}
\hline Number & Ion-nitriding conditions & Remark \\
\hline 1 & None & Fig. 2 \\
2 & $700^{\circ} \mathrm{C}$ for $12 \mathrm{~h}, 10$ torr, $\left[\mathrm{N}_{2}\right] /\left[\mathrm{H}_{2}\right]=1$ & Fig. 2 \\
3 & $800^{\circ} \mathrm{C}$ for $12 \mathrm{~h}, 6$ torr, $\left[\mathrm{N}_{2}\right] /\left[\mathrm{H}_{2}\right]=4$ & Fig. 2 \\
4 & None & Fig. 2 \\
5 & $700^{\circ} \mathrm{C}$ for $4 \mathrm{~h}, 8$ torr, $\left[\mathrm{N}_{2}\right] /\left[\mathrm{H}_{2}\right]=4$ & Fig. 2 \\
6 & $900^{\circ} \mathrm{C}$ for $4 \mathrm{~h}, 6$ torr, $\left[\mathrm{N}_{2}\right] /\left[\mathrm{H}_{2}\right]=1$ & Fig. 2 \\
7 & $900{ }^{\circ} \mathrm{C}$ for $12 \mathrm{~h}, 8$ torr, $\left[\mathrm{N}_{2}\right] /\left[\mathrm{H}_{2}\right]=10$ & Fig. $7($ b) \\
\hline
\end{tabular}




\subsection{Wear test}

The wear tests were performed using a TE-53-type uni-directional sliding wear machine made by Plint and Partners Co., UK. The JIS SKS-95 steel, with hardness $700 \mathrm{HV}$, was used as the against-wear material. The tests were conducted at a constant wear load of $10 \mathrm{~N}$ and a sliding speed of $62.8 \mathrm{~cm} \mathrm{~s}^{-1}$. The surface morphologies of the worn specimens were observed using a Philips 515 SEM. The average wear rate and friction coefficient were automatically calculated by a digital computer during the sliding wear process.

\section{Results and discussion}

\subsection{Corrosion characteristics of ion-nitrided $T i_{50} \mathrm{Ni}_{50}$ and $\mathrm{Ti}_{50} \mathrm{Ni}_{40} \mathrm{Cu}_{10}$ alloys}

Corrosion data from the immersion tests are plotted in Fig. 2 in terms of weight loss versus ion-nitriding conditions. The data from the non-ion-nitrided $\mathrm{Ti}-50 \mathrm{Al}$ specimens (conditions 1 and 4) are also plotted for comparison. In Fig. 2, the symbols in the left half of the diagram are the data points for samples exposed to a $1 \mathrm{M} \mathrm{HCl}$ solution; those in the right half are for samples exposed to $1 \mathrm{M} \mathrm{H}_{2} \mathrm{SO}_{4}$. The ion-nitriding conditions of specimens used in Fig. 2 are listed in Table 1. From Fig. 2, one can see that both $\mathrm{Ti}_{50} \mathrm{Ni}_{50}$ and $\mathrm{Ti}_{50} \mathrm{Ni}_{40} \mathrm{Cu}_{10}$ alloys are more corrosion resistant than the $\mathrm{Ti}-50 \mathrm{Al}$ specimen and the corrosion rate in $\mathrm{H}_{2} \mathrm{SO}_{4}$ solution is higher than that in $\mathrm{HCl}$ solution. At the same time, the ion-nitrided specimens have better corrosion properties than the non-ion-nitrided samples. The higher the nitriding temperatures or the longer the nitriding time, the better the corrosion resistance is. It should also be noted from Fig. 2 that the corrosion resistance of the non-ion-nitrided $\mathrm{Ti}_{50} \mathrm{Ni}_{50}$ alloy is better than that of the non-ion-nitrided $\mathrm{Ti}_{50} \mathrm{Ni}_{40} \mathrm{Cu}_{10}$ alloy. However, ion-nitrided $\mathrm{Ti}_{50} \mathrm{Ni}_{50}$ and $\mathrm{Ti}_{50} \mathrm{Ni}_{40} \mathrm{Cu}_{10}$ alloys have almost the same corrosion resistance.

Surface morphologies after the immersion tests for equiatomic TiNi specimens without and with ion nitriding are shown in Figs. 3 and 4, respectively. Those for $\mathrm{Ti}_{50} \mathrm{Ni}_{40} \mathrm{Cu}_{10}$ specimens are similar to Figs. 3 and 4 and therefore are omitted here. Fig. 3( $a$ and $b$ ) show the surface morphologies of non-ion-nitrided specimens after immersion in a $1 \mathrm{M} \mathrm{HCl}$ solution for 14 days and in a $1 \mathrm{M} \mathrm{H}_{2} \mathrm{SO}_{4}$ solution for 5 days, respectively. Fig. 4(a) shows the surface morphology of a specimen ion nitrided at condition 3 of Table 1 and then immersed in a $1 \mathrm{M} \mathrm{HCl}$ solution for 14 days. Fig. 4(b) shows the surface morphology of a specimen ion nitrided at condition 6 of Table 1 and then immersed in a $1 \mathrm{M} \mathrm{H}_{2} \mathrm{SO}_{4}$ solution for 5 days. The weight loss corresponding to the specimens of Figs. 3 and 4 has been listed in Fig. 2.
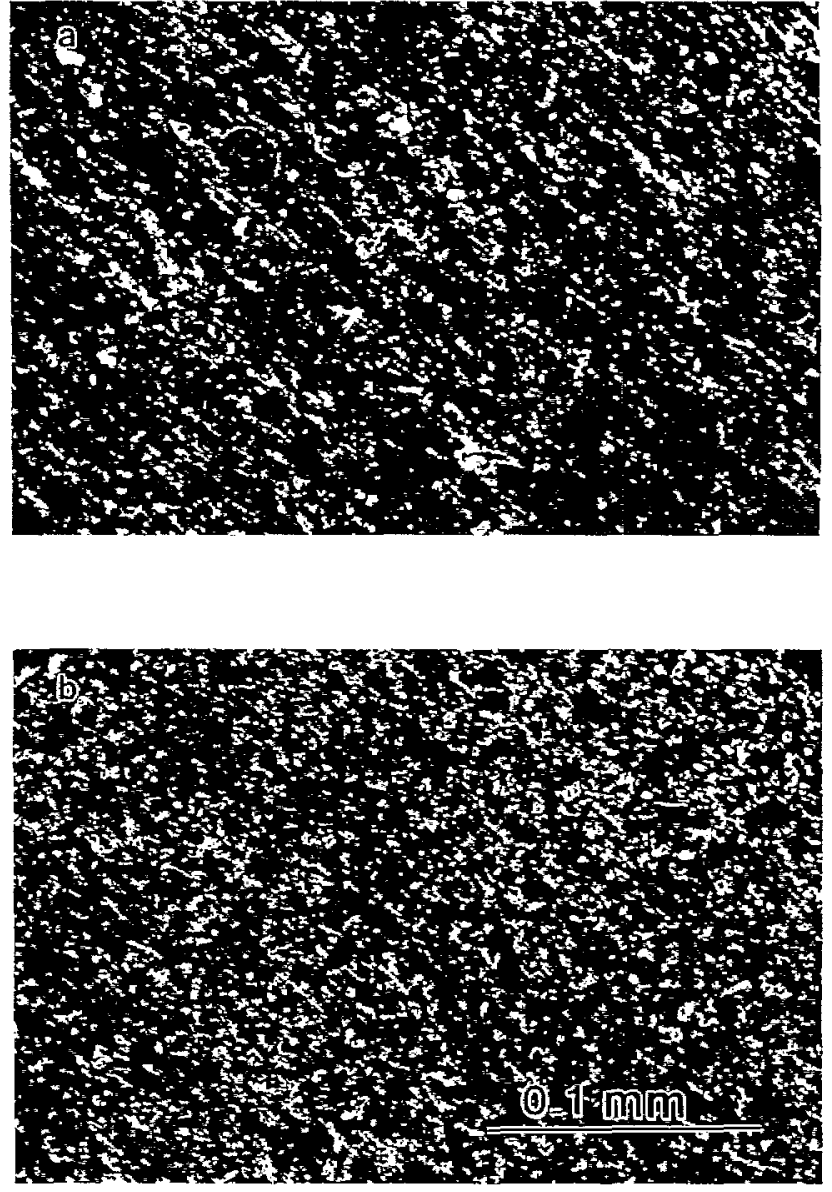

Fig. 3. Scanning electron micrographs of the surface morphology of non-ion-nitrided equiatomic TiNi alloys after immersion in: (a) $1 \mathrm{M}$ $\mathrm{HCl}$ solution for 14 days; (b) in $1 \mathrm{M} \mathrm{H}_{2} \mathrm{SO}_{4}$ solution for 5 days.

From these experimental results shown in Figs. 2-4, one can see that the non-ion-nitrided specimens are easily attacked by $1 \mathrm{M} \mathrm{HCl}$ and $\mathrm{H}_{2} \mathrm{SO}_{4}$ solutions. However, their corrosion properties in both $1 \mathrm{M} \mathrm{HCl}$ and $\mathrm{H}_{2} \mathrm{SO}_{4}$ solutions can be markedly improved by ion nitriding even at low nitriding temperatures and short nitriding times, as indicated from the low weight loss in Fig. 2 and slightly attacked surface morphologies in Fig. 4. Meanwhile, the improvement in corrosion resistance in $1 \mathrm{M} \mathrm{HCl}$ solution after ion nitriding is found to be more evident than in $1 \mathrm{M} \mathrm{H}_{2} \mathrm{SO}_{4}$ solution.

\subsection{Electrochemical potentiodynamic behavior}

Typical potentiodynamic scanning diagrams for equiatomic TiNi specimens treated in a $0.5 \mathrm{M} \mathrm{HCl}$ solution are shown in Fig. 5: (a) without and (b) with ion nitriding at $700^{\circ} \mathrm{C}$ for $2 \mathrm{~h}$. The anodic potentiodynamic polarization curve of Fig. 5 is shown in Fig. 6. Values of the corrosion potential $\phi_{\text {corr }}$ and the corrosion current density $i_{\text {corr }}$ from Tafel extrapolation are listed in Table 2. The data for $\phi_{\text {corr }}$ and $i_{\text {corr }}$ for $\mathrm{Ti}_{50} \mathrm{Ni}_{40} \mathrm{Cu}_{10}$ alloy are also listed in Table 2. From Table 2, one can see that 

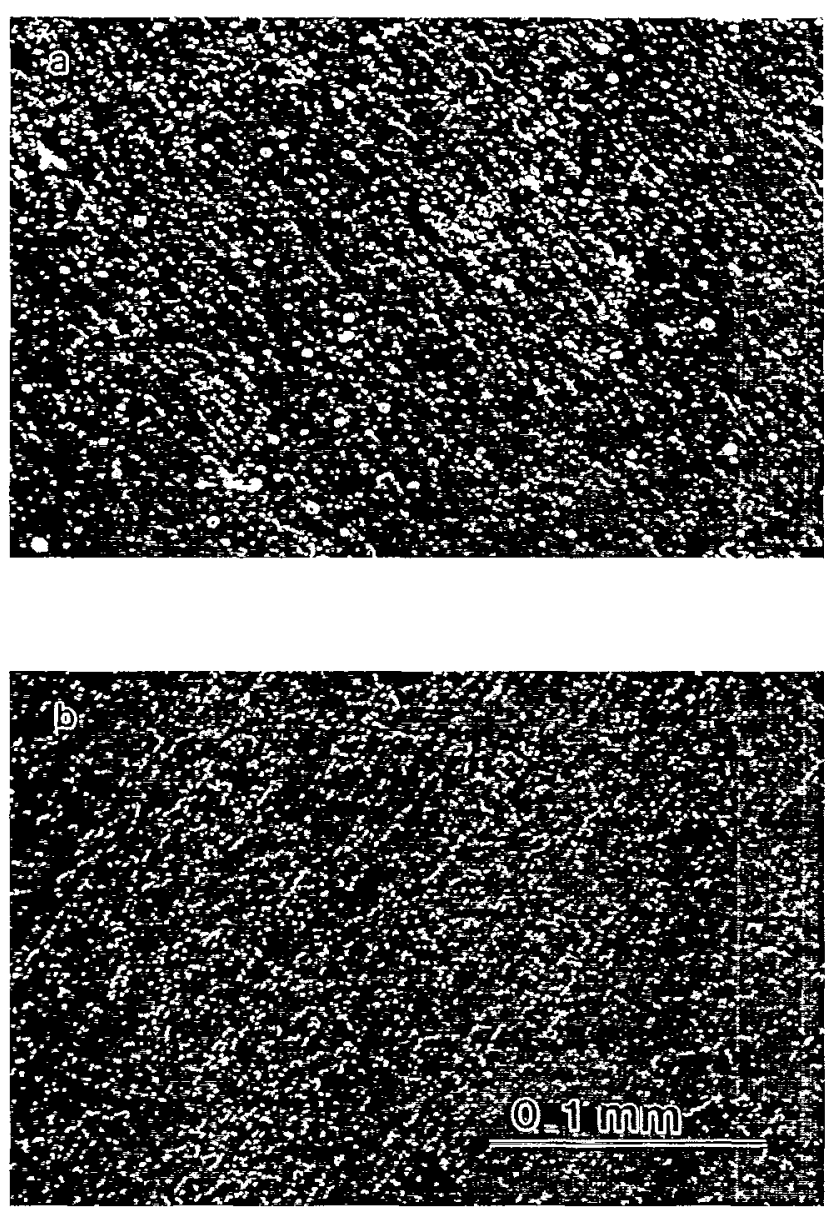

Fig. 4. Scanning electron micrographs of the surface morphology of ion-nitrided equiatomic TiNi alloys after immersion in: (a) $1 \mathrm{M} \mathrm{HCl}$ solution for 14 days; (b) in $1 \mathrm{M} \mathrm{H}_{2} \mathrm{SO}_{4}$ solution for 5 days.

the corrosion potential $\phi_{\text {corr }}$ of ion-nitrided $\mathrm{Ti}_{50} \mathrm{Ni}_{50}$ and $\mathrm{Ti}_{50} \mathrm{Ni}_{40} \mathrm{Cu}_{10}$ specimens is higher, but the current density $i_{\text {corr }}$ is lower, than the corresponding values for nonion-nitrided specimens. This means that the ion-nitrided specimens will exhibit better corrosion properties in the acid solutions.

\subsection{A discussion on the effect of ion nitriding on the corrosion properties of TiNi alloys}

As mentioned in Part I of this study, the ion-nitrided TiNi specimens consist of the TiN and $\mathrm{Ti}_{2} \mathrm{Ni}$ phases in the compound layers [10]. At the same time, higher nitriding temperatures and longer nitriding times cause thicker nitrided layers. It has been reported that TiN is more chemically inert and electrically insulating than titanium alloys [11]. Although the $\mathrm{Ti}_{2} \mathrm{Ni}$ phase was reported to have a poor corrosion resistance [18], we believe that TiN phase existing in the outermost part of the compound layers makes ion-nitrided TiNi alloys more chemically inert than non-ion-nitrided TiNi alloys. This suggestion is also supported by the results of Fig. 2 and Table 2, in which the weight loss and corrosion
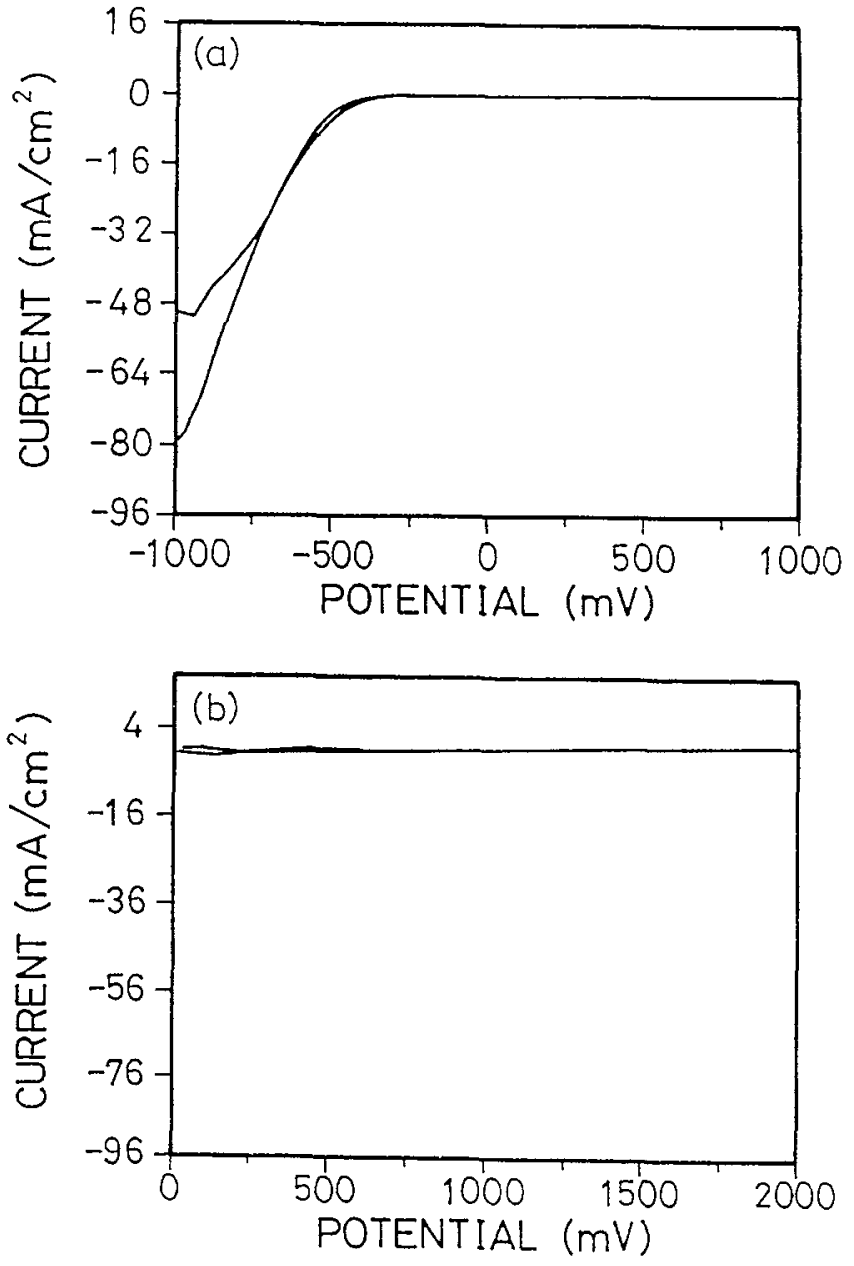

Fig. 5. Potentiodynamic scan diagrams for equiatomic TiNi specimens treated in $0.5 \mathrm{M} \mathrm{HCl}$ solution: (a) non-ion-nitrided specimen; (b) ionnitrided specimen

current density of ion-nitrided TiNi specimens show lower values and the corrosion potential shows a higher value than those of non-ion-nitrided specimens. This is because TiN layer provides better corrosion resistance than non-ion-nitrided TiNi alloys in the acid solutions.

\subsection{Wear characteristics of ion-nitrided TiNi alloys}

Fig. 7 shows the surface morphologies of worn tracks after sliding wear for the equiatomic TiNi specimens without and with ion nitriding ( $a$ and $b$, respectively). Those for $\mathrm{Ti}_{50} \mathrm{Ni}_{40} \mathrm{Cu}_{10}$ specimens are similar to Fig. 7 (a and b) and therefore are omitted here. In Fig. 7(a), a typical worn morphology of TiNi martensite is observed. The TiNi martensite $(\mathrm{Hv}=200)$ is so much softer than the against-wear SKS-95 steel $(\mathrm{Hv}=700)$; hence, the adhesive and abrasive wears occur. The adhesive wear will cause fragments of TiNi martensite to be pulled off and to adhere to the surface of the against-wear SKS95 steel. The abrasive wear introduces ploughing grooves, which originate from the interaction of micro- 


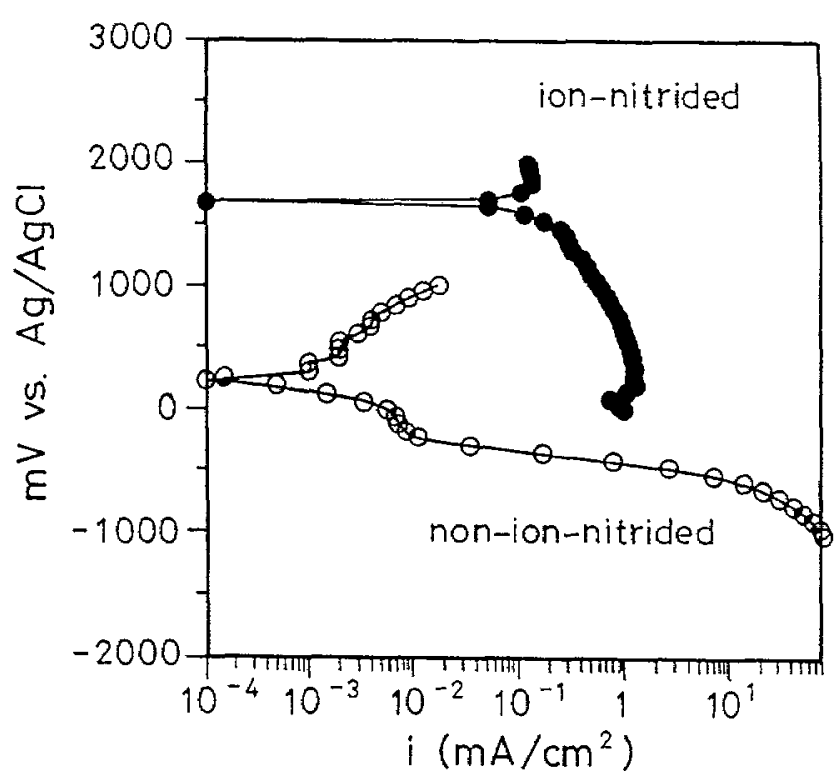

Fig. 6. Anodic potentiodynamic polarization curves for the ion-nitrided and non-ion-nitrided equiatomic TiNi specimens in $0.5 \mathrm{M} \mathrm{HCl}$ solution.
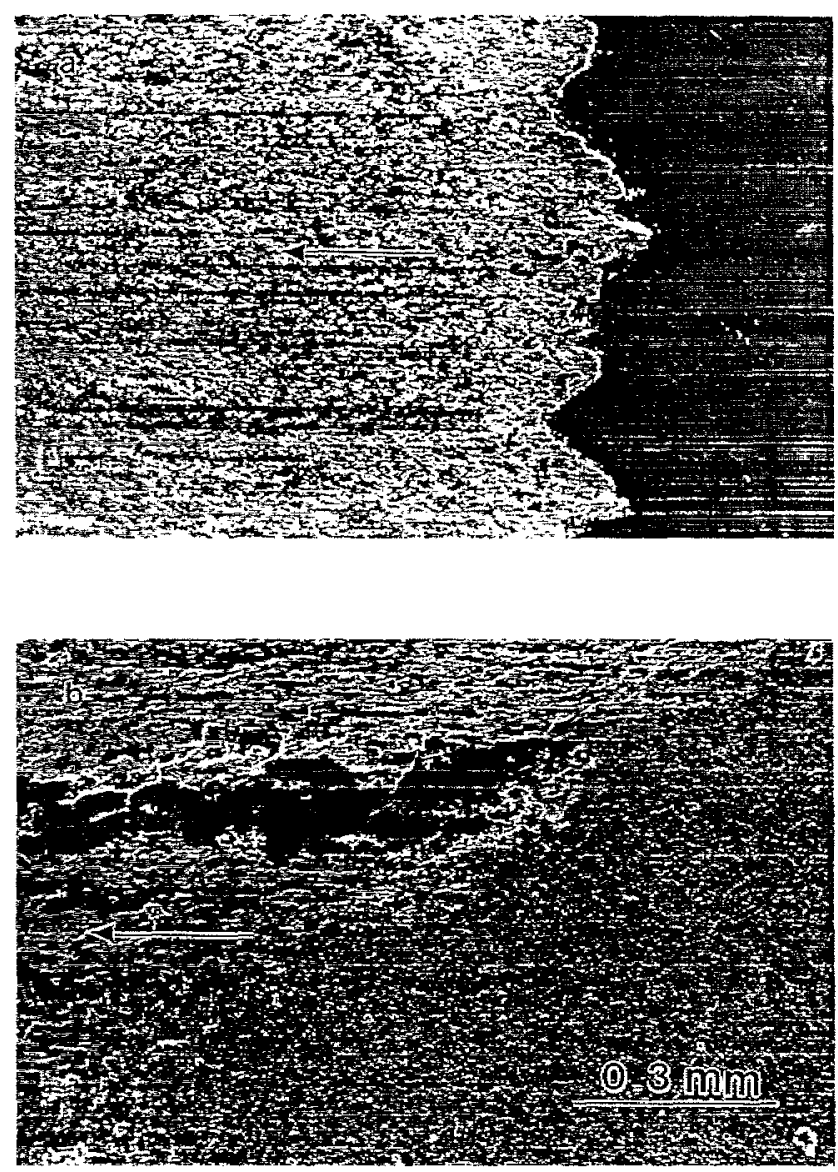

Fig. 7. Surface morphologies of worn tracks after sliding wear for: (a) non-ion-nitrided; (b) ion-nitrided equiatomic TiNi specimens.
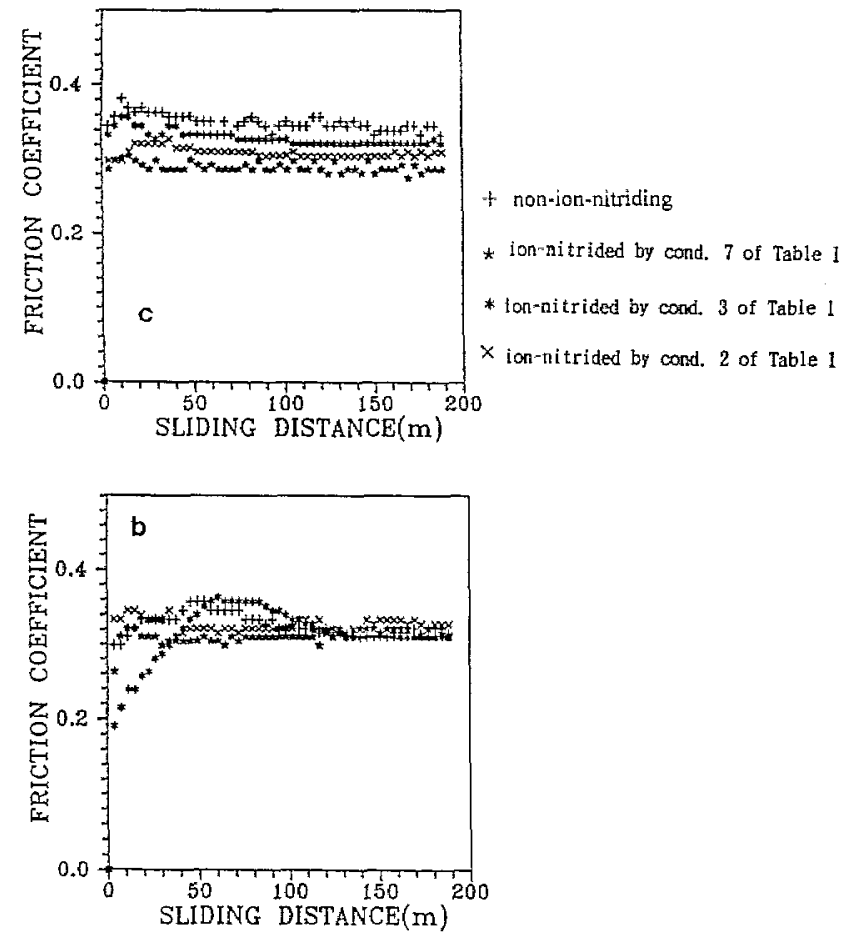

Fig. 8. The friction coefficients for the ion-nitrided TiNi specimens at various nitriding conditions: (a) $\mathrm{Ti}_{50} \mathrm{Ni}_{50}$; (b) $\mathrm{Ti}_{50} \mathrm{Ni}_{40} \mathrm{Cu}_{10}$ alloys.

cutting and plastic deformation [19]. As presented in Part I of this study, the surface hardness of TiNi martensite can be rapidly raised by ion nitriding. This feature originates from the hard layers of TiN and $\mathrm{Ti}_{2} \mathrm{Ni}$ compounds. The thicker the compound layers, the higher the surface hardness. These hard compound layers will affect the wear resistance of TiNi specimens. As shown in Fig. 7(b), main adhesive wear morphology occurs; however, now, fragments of SKS-95 steel have been adhesively transferred to the $\mathrm{TiN} / \mathrm{Ti}_{2} \mathrm{Ni}$ compound layers, instead of the TiNi martensite being transferred to the steel, due to their significant difference of hardness.

Figs. 8 and 9 shows friction coefficients and wear rates, respectively, for the ion-nitrided $\mathrm{Ti}_{50} \mathrm{Ni}_{50}$ and $\mathrm{Ti}_{50} \mathrm{Ni}_{40} \mathrm{Cu}_{10}$ specimens at various nitriding conditions of Table 1. In these figures, friction coefficients and wear rates of ion-nitrided specimens are much lower than those of non-ion-nitrided specimens. These results come from the fact that the wear interfaces are $\mathrm{TiN} / \mathrm{Ti}_{2} \mathrm{Ni}$ compound layers and SKS-95 steel, and hence friction coefficients and wear rates maintain low values due to their high hardness. This indicates that the wear characteristics of TiNi specimens can be effectively improved by ion nitriding because $\mathrm{TiN} / \mathrm{Ti}_{2} \mathrm{Ni}$ compound layers provide an important contribution to the improvement of wear resistance. In other words, the ion-nitrided TiNi shape memory alloys, being hardened by $\mathrm{TiN} / \mathrm{Ti}_{2} \mathrm{Ni}$ compounds, can exhibit excellent wear resistance and a low friction coefficient. 
Table 2

Corrosion data of the Tafel slope extrapolation calculated from Fig. $6(0.5 \mathrm{M} \mathrm{HCl}$ solution)

\begin{tabular}{lll}
\hline Sample & Corrosion potential $\phi_{\text {corr }}(\mathrm{V}$ versus $\mathrm{Ag} / \mathrm{AgCl})$ & Corrosion current density $i_{\text {corr }}\left(\mathrm{mAcm} \mathrm{cm}^{-2}\right)$ \\
\hline $\mathrm{Ti}_{50} \mathrm{Ni}_{50}$ (non ion-nitrided) & +0.22 & 0.0018 \\
$\mathrm{Ti}_{50} \mathrm{Ni}_{40} \mathrm{Cu}_{10}$ (non ion-nitrided) & +0.07 & 0.0400 \\
$\mathrm{Ti}_{50} \mathrm{Ni}_{50}$ (ion-nitrided) & +1.68 & 0.0011 \\
$\mathrm{Ti}_{50} \mathrm{Ni}_{40} \mathrm{Cu}_{10}$ (ion-nitrided) & +1.70 & 0.0010 \\
\hline
\end{tabular}

aion nitrided at $700^{\circ} \mathrm{C}$ for $2 \mathrm{~h}$ and 6 torr with $\left[\mathrm{N}_{2}\right] /\left[\mathrm{H}_{2}\right]=10$.

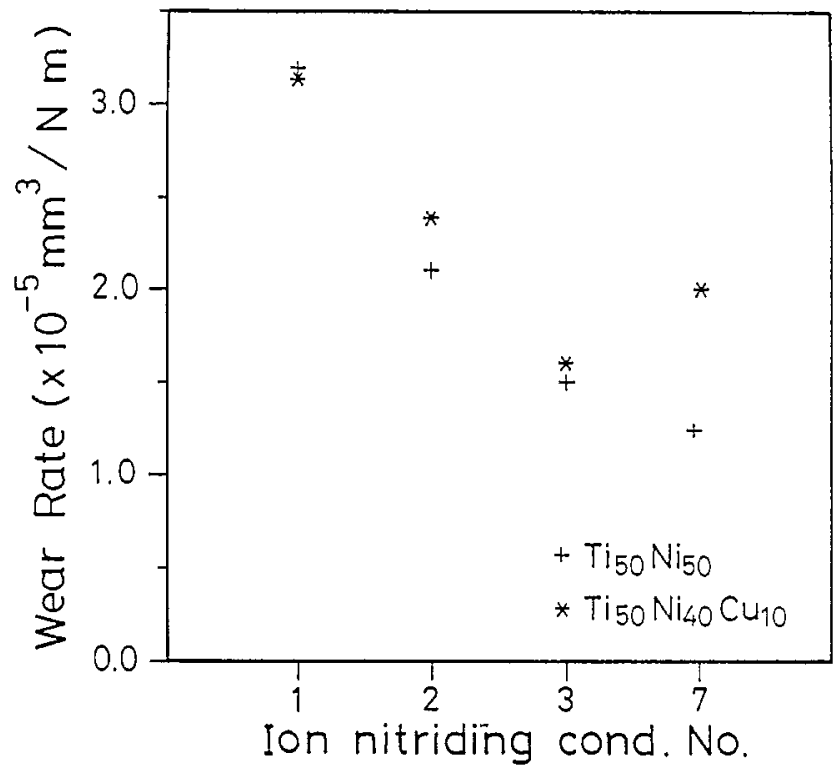

Fig. 9. The wear rates for the ion-nitrided $\mathrm{Ti}_{50} \mathrm{Ni}_{50}$ and $\mathrm{Ti}_{50} \mathrm{Ni}_{40} \mathrm{Cu}_{10}$ specimens at various nitriding conditions. The ion-nitriding conditions are listed in Table 1.

\section{Conclusions}

In this study, the corrosion properties and wear characteristics of equiatomic TiNi shape memory alloys with and without ion nitriding were investigated. The experimental results indicate that the non-ion-nitrided specimens are easily attacked by $\mathrm{HCl}$ and $\mathrm{H}_{2} \mathrm{SO}_{4}$ solutions. The corrosion rate of TiNi alloys in both $\mathrm{HCl}$ and $\mathrm{H}_{2} \mathrm{SO}_{4}$ solutions can be markedly improved by ion nitriding. The improvement in corrosion resistance in $\mathrm{HCl}$ solution is more evident than that in $\mathrm{H}_{2} \mathrm{SO}_{4}$ solution. The improved corrosion resistance in these solutions is attributed to the TiN compound formed on the outermost part of the ion-nitrided layers. The wear characteristics of $\mathrm{Ti}_{50} \mathrm{Ni}_{50}$ and $\mathrm{Ti}_{50} \mathrm{Ni}_{40} \mathrm{Cu}_{10}$ shape memory alloys can also be effectively improved by ion nitriding. The ion-nitrided TiNi specimens, being hardened by $\mathrm{TiN} / \mathrm{Ti}_{2} \mathrm{Ni}$ compounds, can exhibit an excellent wear resistance and a low friction coefficient.

\section{Acknowledgement}

The authors are pleased to acknowledge the financial support of this research by the National Science Council (NSC), Republic of China under Grant No. NSC842216-E002-027.

\section{References}

[1] S. Miyazaki, K. Otsuka, Y. Suzuki, Scripta Metall. 15 (1981) 287-292.

[2] S. Miyazaki, Y. Ohmi, K. Otsuka, Y. Suzuki, ICOMAT-82, J. Phys. 43 (1982) 255-260.

[3] S. Miyazaki, T. Imai, Y. Igo, K. Otsuka, Metall. Trans. A 17A (1986) 115-120.

[4] Y. Oshia, S. Miyazaki, Corros. Engng 40 (1991) 1009-1025.

[5] K.N. Melton, J.D. Harrison, Proc. International Conference on Shape Memory and Superelastic Technologies, SMST-94, 1994, pp. 187-196.

[6] K. Endo, R. Sachdeva, Y. Araki, Ohno, Proc. International Conference on Shape Memory and Superelastic Technologies, SMST-94, 1994, pp. 197-201.

[7] S. Lombardi, L.H. Yahia, J.E. Klemberg-Sapieha, D.L. Piron, A. Selman, C.H. Rivard, G. Drouin, Proc. International Conference on Shape Memory and Superelastic Technologies, SMST-94, 1994, pp. 221-226.

[8] G. Rondelli, B. Vicentini, A. Cigada, Corros. Sci. 30 (1990) 805.

[9] American Society for Metals, ASM Handbook, vol. 4, 9th ed., ASM, Metals Park, OH, 1991, p. 387.

[10] S.K. Wu, C.L. Chu, H.C. Lin, Surf. Coatings Technol. 92 (1997) 197-205.

[11] J. Aromma, H. Ronkainen, A. Mahiout, S.-P. Hannula, Surf. Coatings Technol. 49 (1991) 353.

[12] M. Taguchi, J. Kurihara, Mater. Trans. Jap. Inst. Metals 33 (7) (1992) 691.

[13] Y. Massiani, P. Gravier, J.P. Crousier, L. Fedrizzi, M. Dapor, V. Micheli, L. Roux, Surf. Coatings Technol 52 (1992) 159.

[14] I.M. Penttinen, A.S. Korhonen, E. Harju, M.A. Turkia, O. Forsen, E.O. Ristolainen, Surf. Coatings Technol. 50 (1992) 161.

[15] F.D. Lai, T.I. Wu, J.K. Wu, Surf. Coatings Technol. 58 (1993) 79.

[16] A. Takasaki, K. Ojima, Y. Taneda, Scr. Metall. 30 (9) (1994.) 1095-1098.

[17] C.L. Chu, S.K. Wu, Surf. Coatings Technol. 78 (1996) 219-226.

[18] R.S. Ruta, Corrosion 28 (3) (1993) 217-221.

[19] O. Vingsbo, Wear of Materials, ASME, New York, 1979, pp. $620-635$. 